\title{
A Study on Zeolite Performance in Waste Treating Ponds for Treatment of Palm Oil Mill Effluent
}

\author{
M. Halim Shah Ismail ${ }^{*}$, Shazryenna Dalang, Syafiie Syam, Shamsul Izhar \\ Department of Chemical and Environmental Engineering, Faculty of Engineering, \\ Universiti Putra Malaysia, Serdang, Malaysia \\ Email: *mshalim@eng.upm.edu.my
}

Received April 27, 2013; revised May 29, 2013; accepted July 4, 2013

Copyright (c) 2013 M. Halim Shah Ismail et al. This is an open access article distributed under the Creative Commons Attribution License, which permits unrestricted use, distribution, and reproduction in any medium, provided the original work is properly cited.

\begin{abstract}
Oil palm currently occupies the largest acreage of farm land in Malaysia. In 2011, the production of palm oil in Malaysia was recorded as 19.8 million tons which has led to a huge amount of wastewater known as palm oil mill effluent (POME). This work focuses on the ponding system which acts as wastewater treatment plant in order to treat POME. The conventional ponding system applied in mills consists of a series of seven ponds. The maintenance costs of the pond are expensive thus study of alternative methods is needed. POME treatment using zeolite shows a potential to overcome the problem. Samples collected from selected ponds are tested and analyzed using water analyzer method. Result from adsorption by zeolite shows a significant reduction of COD, BOD, Fe, Zn, Mn and turbidity. This shows that zeolite is highly potential to be applied as adsorbent in the POME treatment plants. The results here may lead to lower maintenance cost, lower quantity of treatment ponds and lesser land occupied for the treatment of POME in Malaysia.
\end{abstract}

Keywords: Palm Oil Mill Effluent (POME); Zeolite; Wastewater Treatment

\section{Introduction}

Palm oil is one of the world's most rapidly expanding equatorial crops. Indonesia and Malaysia are the two largest oil palm producing countries and is rich with numerous endemic, forest-dwelling species. Malaysia has a tropical climate and is prosperous in natural resources. Oil palm currently occupies the largest acreage of farmed land in Malaysia [1]. Over the recent years, there has been a growing concern about the discharge of oil-containing industrial wastewater into the ecosystem. Palm oil processing in Malaysia annually produces a huge amount of wastewater known as palm oil mill effluent (POME). POME is a viscous brown liquid with fine suspended solids at $\mathrm{pH}$ ranging between 4 and 5 [2]. Characteristics of POME are tabulated in Table 1. In the process of palm oil milling, POME is generated through sterilization of fresh oil palm fruit bunches, clarification of palm oil and effluent from hydrocyclone operations [3]. It is estimated that about $0.5-0.75$ tons of POME are discharged from the mill for every ton of fresh fruit bunch (FFB) [4]. In Malaysia about 53 million $\mathrm{m}^{3}$ POME is

*Corresponding author. being produced every year based on palm oil production since 2005. Therefore, the challenge of converting POME into an environmental friendly waste requires an efficient treatment and effective disposal.

Ponding systems are easy operating systems but they occupy a vast amount of land mass, relatively long hydraulic retention time (45 - 60 days) and bad odor. Moreover, it is difficult to maintain the liquor distribution and biogas collection which leads to harmful effect on the environment $[5,6]$. Another major disadvantage of using ponding system is the formation of scum and solids that tend to build up at the bottom of the pond. The sludge and scum will clump together inside the pond lowering the treatment efficiency. Therefore, the system requires regular desludging process by either using submersible pumps or excavators. Since the POME treatment applied at mills consists of seven ponds, the maintenance cost for all the ponds is very costly. Due to these facts, palm oil mills face the challenge of balancing the environmental protection, its economic viability and sustainable development. There is an urgent necessity to find an approach to preserve the environment while keeping the economy growing. 
Table 1. Characteristic of untreated POME [15].

\begin{tabular}{|c|c|}
\hline Parameter & Concentration ${ }^{*}$ \\
\hline $\mathrm{pH}$ & 4.7 \\
\hline Temperature & $80-90$ \\
\hline BOD 3-day, $30^{\circ} \mathrm{C}$ & 25,000 \\
\hline COD & 50,000 \\
\hline Total Solids & 40,500 \\
\hline Suspended Solids & 18,000 \\
\hline Total Volatile Solids & 34,000 \\
\hline Ammoniacal-Nitrogen & 35 \\
\hline Total Nitrogen & 750 \\
\hline Phosphorus & 18 \\
\hline Potassium & 2,270 \\
\hline Magnesium & 615 \\
\hline Calcium & 439 \\
\hline Boron & 7.6 \\
\hline Iron & 46.5 \\
\hline Manganese & 2.0 \\
\hline Copper & 0.89 \\
\hline Zinc & 2.3 \\
\hline
\end{tabular}

*All units are in mg/L except $\mathrm{pH}$ and Temperature $\left({ }^{\circ} \mathrm{C}\right)$.

Zeolites are safe, naturally occurring crystalline aluminosilicate that have a three-dimensional structure; aluminum, silicon and oxygen which are arranged in a regular structure of $\left[\mathrm{SiO}_{4}\right]$ - and $\left[\mathrm{AlO}_{4}\right]$-tetrahedral units that form a framework with small pores (also called tunnels, channels or cavities) of about $0.1-2 \mathrm{~nm}$ diameter running through the material [7]. In these small channels, solid, liquid and gaseous substances can be trapped [8]. High ion exchange capacity, the molecular sieve properties and the relatively high surface area $[9,10]$ make zeolite a promising adsorbent media for treating effluent with different suspended solids [11]. Zeolites have wide application as gas and odor filter, as a part of animal feed, and as ammonia removers from different wastewaters $[12,13]$. The metallic ions sorbent behavior of natural zeolite has been also studied by several researches, and it has been recognized as a promising sorbent for heavy metals [14]. Despite these various researches that have shown the feasibility of its application for removal of heavy metals from aqueous solution, limited studies have been carried out on COD, BOD and turbidity removal in POME treatment. Thus, this study will apply the optimum condition for zeolite to treat POME in order to determine the performance of zeolite for POME treatment at different ponds. A successful result could minimize the quantity of treatment ponds in palm oil mill in order to minimize the annual operation cost and the area of land used.

\section{Materials and Methods}

\subsection{Sources of POME Samples}

This study was conducted at one of palm oil mill in Malaysia. This mill has the capacity to process 30 ton/h of FFB. Since the factory operates continuously for 24 hours, it is capable to process 720 ton/d of FFB. Roughly, the mill will produce 360 ton/d of POME. POME treatment applied by the mill was the ponding system which consists of several ponds and ends up with wastewater treatment plant which is an extended aeration type before discharging the effluent into the river. The ponds are separated by their function as in Table 2. The percentage of removal is further studied to identify if this laboratory scale treatment can be applied. Natural zeolite (clinoptilolite) that was used in this study was supplied from Slovakia. Prior to the experiment, the zeolite was crushed and passed through a No. 20 sieves before it was washed with distilled water and dried in an oven at $120^{\circ} \mathrm{C}$ for $18 \mathrm{~h}$.

\subsection{POME Analysis}

The analysis of POME characterization in this study is limited to COD, BOD, heavy metals and turbidity only. The POME is characterized before and after the adsorption by zeolite.

The COD is used as a measure of the oxygen equivalent of the organic matter content of a sample that is susceptible to oxidation by a strong chemical oxidant. In this project, the open reflux method of COD analysis is used as it is suitable for a wide range of waste where a large sample size is preferred. The procedures for COD analysis consist of apparatus preparation, sample and reagent preparation and reading method. For apparatus preparation, this analysis requires the reflux apparatus which consists of Digital Reactor Block (DRB 200), micro bu-

Table 2. POME treatment ponds.

\begin{tabular}{cc}
\hline Sample Real Pond & Sample Label \\
\hline Cooling & Pond 1 \\
Mixing & Pond 2 \\
Anaerobic 1 & Pond 3 \\
Anaerobic 2 & Pond 4 \\
Facultative & Pond 5 \\
Algae 1 & Pond 6 \\
Algae 2 & Pond 7 \\
\hline
\end{tabular}


rette, pipette, conical flask and culture tubes $(16 \times 100$ $\mathrm{mm})$.

To begin the experiment, $2.5 \mathrm{~mL}$ of sample is placed in the culture tube. $1.5 \mathrm{~mL}$ of $0.01167 \mathrm{M}$ potassium dichromate digestion solution is added. $3.5 \mathrm{~mL}$ sulphuric acid is carefully added as the formation of acid layer under the sample-digestion solution layer is required. The culture tubes are tightly cap and inverted several times to allow sample to be completely mixed. The culture tubes are placed in the block digester, preheated to $150^{\circ} \mathrm{C}$ and refluxed for 2 hours behind a protective shield. The culture tubes are then taken out and cooled to room temperature. The culture tubes caps are removed and 0.05 to $0.10 \mathrm{~mL}$ ( 1 to 2 drops) ferroin indicator is added. The samples are titrated with standardized 0.10 M FAS while stirred rapidly. Reading is taken when the end point is reached. The endpoint is a sharp color that changed from blue-green to reddish brown, although the blue-green may reappear within minutes. The blank samples were prepared in the same manner.

The COD value of the sample was calculated using the following equation:

$$
M_{\mathrm{FAS}}=\frac{V_{\mathrm{K}_{2} \mathrm{CrO}_{7}}}{V_{\mathrm{FAS}}} \times 0.1 \mathrm{COD}=\frac{(A-B) \times M \times 8000}{V_{\text {sample }}}
$$

where $M_{\mathrm{FAS}}=$ molarity of FAS solution (M), $V_{\mathrm{K} 2 \mathrm{CrO} 7}=$ volume $0.0167 \mathrm{M} \mathrm{K}_{2} \mathrm{CrO}_{7}(\mathrm{~mL}), V_{\mathrm{FAS}}=$ volume FAS used in titration (mL), $A=\mathrm{mL}$ FAS used for blank, $B=$ mL FAS used for sample, $M=$ molarity of FAS.

The procedures for BOD analysis consist of incubation bottles $-300 \mathrm{ml}$ bottles, incubator-thermostatically controlled at $20^{\circ} \mathrm{C} \pm 1^{\circ} \mathrm{C}$, burette, pipette $2 \mathrm{ml}$, measuring cylinder $-100 \mathrm{ml}$ and $200 \mathrm{ml}$, aluminum foil and standard laboratory glassware. There are 3 parts in measuring BOD; sample pre-treatment, preparation of dilution water and the measurement of BOD. For sample pre-treatment, $\mathrm{pH}$ for all the samples is checked. Sample with $\mathrm{pH}$ not between 6.0 and 8.0 is adjusted to $\mathrm{pH}$ to 7.0 to 7.2 using $\mathrm{H}_{2} \mathrm{SO}_{4}$ solution. $\mathrm{NaOH}$ solution is used to adjust the sample with $\mathrm{pH}$ lower than 6.0. The $\mathrm{NaOH}$ should be in such strength that the quantity of reagent does not dilute the sample by more than $0.5 \%$. The $\mathrm{pH}$ of dilution water should not be affected by the lowest sample dilution.

In preparing dilution water, a desired working volume of source water is transferred to a suitably sized bottle. The dissolve oxygen concentration is checked so at least $7.5 \mathrm{mg} / \mathrm{L}$ is existed before it can be used for BOD tests. DO is added by shaking or by aerating it with organic-free filtered air. Finally $1 \mathrm{~mL}$ each of phosphate buffer, magnesium sulphate $\left(\mathrm{MgSO}_{4}\right)$, calcium chloride $\left(\mathrm{CaCl}_{2}\right)$ and ferrous chloride $\left(\mathrm{FeCl}_{3}\right)$ solutions per liter of water is added. Dilution of sample is also required. In this experiment, the dilution is based on 1 to $5 \%$ for raw and settled wastewater. To measure BOD, ten BOD 300
$\mathrm{mL}$ bottles are prepared, eight for POME samples and two for blank samples. All bottles are labelled accordingly to indicate day- 0 and day-5 to avoid confusion. 1 $\mathrm{mL}$ of diluted sample is added into the sample bottles and $1 \mathrm{~mL}$ of deionised water is added into the blank samples. Dilution water is added until it reached the neck of the bottles for complete filling. The sample is then mixed by inverted the bottles several times. The day- 5 bottles are wrapped with aluminium foil and are incubated for 5 days at $20^{\circ} \mathrm{C}$.

The $\mathrm{DO}$ is determined directly for day- 0 samples by adding $1 \mathrm{~mL}$ of manganese sulphate $\left(\mathrm{MnSO}_{4}\right)$ solution followed by $1 \mathrm{~mL}$ of iodine-azide reagent. The bottles are then sealed and inverted a few times to allow mixing. $1 \mathrm{~mL}$ of concentrated $\mathrm{H}_{2} \mathrm{SO}_{4}$ solution is added after the suspension has fully settled. Again, the bottles are sealed and mixed by inverting several times until dissolution complete. $200 \mathrm{~mL}$ of the sample are taken out and titrated with sodium thiosulphate solution. Few drops of starch indicator are added and titrated until the samples are colorless. This procedure is repeated for the day- 5 sample and blank bottle after the five days of incubation. The BOD is determined by the formula below:

$$
\mathrm{BOD}[\mathrm{mg} / \mathrm{L}]=\frac{(D 1-D 2) \times 300}{\text { sample }[\mathrm{ml}]}
$$

where $D 1=$ DO of diluted sample immediately after preparation $(\mathrm{mg} / \mathrm{L}), D 2=\mathrm{DO}$ of diluted sample after 5 days of incubation at $20^{\circ} \mathrm{C}(\mathrm{mg} / \mathrm{L})$.

The heavy metal analysis is examined using the Atomic Absorption Spectroscopy (Shimadzu). Substance must first be dissolved in a liquid, dried and then atomized to vaporize the substance into gas atoms. Sample is prepared by adding $5 \%$ of nitric acid and refluxed at $95^{\circ} \mathrm{C}$ for 15 minutes. Then, the sample is filtered with $0.45 \mu \mathrm{m}$ filter paper. The standard solution is prepared for $\mathrm{Zn}, \mathrm{Fe}$ and $\mathrm{Mn}$ and based on the permissible limit concentration.

The turbidity is analyzed by $2100 \mathrm{~N}$ and AN Turbidity Meter, which adopted the Nephelometry method. The Nephelometry method is the standard method for measuring turbidity because of the method's sensitivity, precision, and applicability over a wide range of particle size and concentration. The POME samples were measured directly without pretreatment.

\section{Results and Discussion}

\subsection{Characteristics of POME in Ponding System}

The parameters analyzed in this study are COD, BOD, Fe, $\mathrm{Zn}$ and $\mathrm{Mn}$ and turbidity. The characterization of the samples collected from the mill by the normal method without zeolite is summarized in Table 3 . Pond 2 con- 
Table 3. Analysis results of POME at Mill Site for ponding system and zeolite adsorption.

\begin{tabular}{ccccc}
\hline & \multicolumn{3}{c}{ Pond Number } & \\
\cline { 2 - 5 } Parameter & 2 & 4 & 5 & 7 \\
\hline COD (mg/L) & 26,880 & 3264 & 2112 & 330 \\
BOD (mg/L) & 66,000 & 420 & 270 & 8.4 \\
pH & 4.4 & 7.5 & 7.7 & 13.6 \\
Turbidity (NTU) & 4352 & 100 & 54.3 & 0.7428 \\
Fe (mg/L) & 11.5206 & 2.9217 & 0.9479 & 0.2616 \\
Mn (mg/L) & 1.7832 & 0.3226 & 0.34495 & 0.1681 \\
Zn (mg/L) & 0.7456 & 0.5453 & 0.1221 \\
\hline
\end{tabular}

tains higher COD concentration (26880 mg/L) as compared to Pond 4, Pond 5 and Pond 7 where COD concentrations are $3264 \mathrm{mg} / \mathrm{L}, 2112 \mathrm{mg} / \mathrm{L}$ and $768 \mathrm{mg} / \mathrm{L}$, respectively. POME characteristics in Table $\mathbf{3}$ clearly shows that Pond 2 has the highest value of all parameters due to the presence of high degradable organic matter, which most probably caused by the presence of unrecovered palm oil.

The BOD concentration at Pond 2 is 66,000 mg/L, while Pond 4, Pond 5 and Pond 7 has the BOD concentrations of $420 \mathrm{mg} / \mathrm{L}, 270 \mathrm{mg} / \mathrm{L}$ and $330 \mathrm{mg} / \mathrm{L}$, respecttively. Similar to COD concentration, Pond 2 contains less dissolve oxygen as it has higher BOD concentration compared to other treatment ponds.

The turbidity of Pond 2 is 4352 NTU, which indicates poor aesthetic characteristic. The turbidity level for wastewater should comply with the turbidity for drinking water, which should not exceed 1000 NTU. Pond 2 shows acidic behavior of $\mathrm{pH} 4.4$ and this is comparable to Ma et al. on characterization of POME [15]. Normally palm oil mill wastewater is low in $\mathrm{pH}$ because of the organic acids produced during the fermentation process. However, throughout the POME treatment by ponding system, the $\mathrm{pH}$ at Pond 4, Pond 5 and Pond 7 show alkaline behavior with $\mathrm{pH}$ of 7.5, 7.7 and 8.4, respectively. POME samples were considered a non-toxic wastewater as no chemical was added in the oil extraction process. However, it is identified as a major source of aquatic pollution caused by depleting dissolved oxygen when discharged untreated into the water bodies [16].

\subsection{COD Analysis}

Figure 1 illustrates the COD concentrations of normal POME treatment (without zeolite) and treatment with zeolite. The figure clearly indicates both COD concentration is degrading from Pond 2 to Pond 7. According to Sethupathi [17], the organic substance of POME is generally biodegradable; therefore treatment by biodegradeable process could be suitable, which are based com-

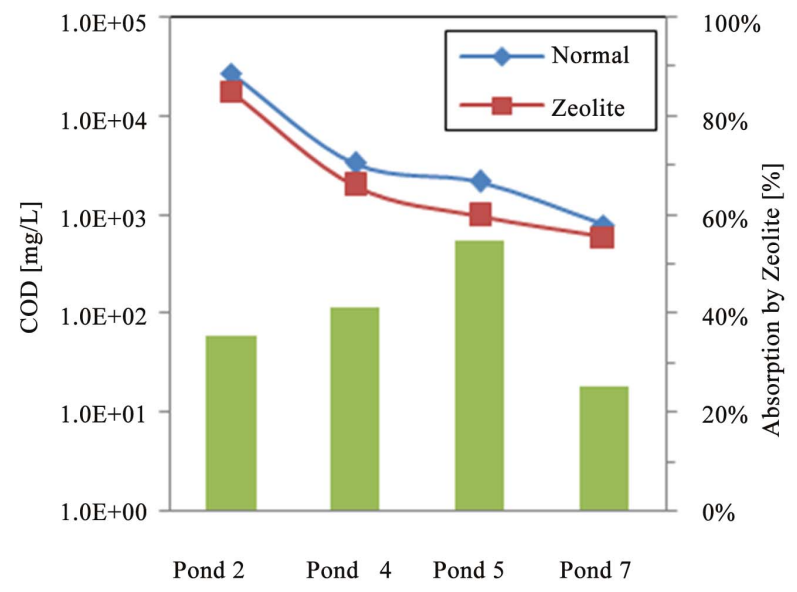

Figure 1. COD concentration after POME was treatedwith and without zeolite as adsorbent.

monly on anaerobic, aerobic and facultative processes. This is evident by the degradation of COD concentration at Pond 2 to Pond 7, where the COD concentration of Pond 2, Pond 4, Pond 5 and Pond 7 is 26,680 mg/L, 3264 $\mathrm{mg} / \mathrm{L}, 2112 \mathrm{mg} / \mathrm{L}$, and $768 \mathrm{mg} / \mathrm{L}$ respectively.

The treatment of POME with zeolite in Figure 1 shows the COD concentration that all samples are decreasing. The COD concentration at Pond 2 reduced to $17,280 \mathrm{mg} / \mathrm{L}$, lower than that without zeolite. The COD concentration is also reduced at Pond 4, Pond 5 and Pond 7 to $1920 \mathrm{mg} / \mathrm{L}, 960 \mathrm{mg} / \mathrm{L}$, and $576 \mathrm{mg} / \mathrm{L}$, respectively. The acceptable conditions for discharge of industrial effluent containing chemical oxygen demand for specific trade or industry sector is $200 \mathrm{mg} / \mathrm{L}$ as the discharge limit. Therefore, to comply with the regulation, but the mill has abio-polishing plant where the COD concentration can further be reduced.

Figure 1 (bar graph) indicates that zeolite has different capacity of COD sorption at different type of POME characteristic. The highest removal percentage of COD concentration is found at Pond 5 (54.6\%). Pond 5 is a facultative pond where according to Gray [18], faculta- 
tive ponds are characterized by having an upper aerobic and a lower anaerobic zone with active purification occurring in both.

The sorption capacity of zeolite at Pond 4 is almost similar as the COD concentration reduction at Pond 5 (41.2\%). This identifies that zeolite can perform better at condition where anaerobic and aerobic condition exists. The other removal percentage of COD concentration is at Pond 7 (25\%) and Pond 2 (35.7\%). Microwave incinerated rice husk ash (MIRHA) have been reported as an adsorbent in POME treatment, but the capacity of COD reduction for MIRHA is $41 \%$. This indicates the COD sorption capacity of zeolite is better than MIRHA.

\subsection{BOD Analysis}

Figure 2 indicates the BOD concentrations after POME was treated without (normal) and with zeolites. Pond 2 which contains the raw POME after a cooling process has the highest concentration of BOD (66000 mg/L) when zeolite was not used. High concentration of BOD indicates the raw POME is mixed with the digested POME and the BOD concentration signifies less concentration of dissolve oxygen. However, the BOD concentration the present study is three times higher than the sited BOD concentration cited in literature [15] where BOD concentration of typical POME is $25,000 \mathrm{mg} / \mathrm{L}$. This is maybe due to the desludging activity at Pond 3 (Aerobic 1), as a result from the accumulation of organic substances at Pond 2. Higher BOD concentration shows that there is a high competition for the dissolve oxygen by the suspended, dissolved substances and micro organism in the POME. The concentrations of BOD did not change much after Pond 2 with Pond 4, 5 and 7 obtained 420, 270 and $330 \mathrm{mg} / \mathrm{L}$, respectively. The organic substance of POME is generally biodegradable; therefore treatment by biodegradable process could be suitable, which are based commonly on anaerobic, aerobic and facultative processes. Figure 2 demonstrates the concentration of BOD treated with zeolite at Pond 2. It clearly shows the reduction of BOD concentration. The BOD

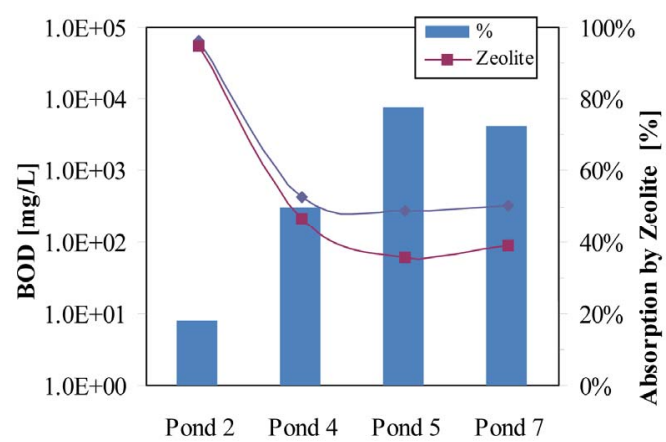

Figure 2. BODconcentration in ponds treated without and with zeolite as adsorbent. concentration reduces from 54,000 mg/L (Pond 2), 210 mg/L (Pond 4), 60 mg/L (Pond 5) and 90 mg/L (Pond 7). This decrement that is lower than treatment without zeolite proves that zeolite has a high capacity of BOD concentration adsorption.

Figure 2 (bar graph) demonstrates the percentage of BOD removal by zeolite. The highest BOD percentage removal is found at Pond 5, which is $77.8 \%$. Adsorption at Pond 2 sample is poor as zeolite can only remove $18.2 \%$ of the BOD concentration. Pond 4 and Pond 7 has the percentage of BOD concentration removal of $50 \%$ and $72.73 \%$, respectively. The performance of zeolite as BOD remover is excellent as it can reduce the BOD concentration up to $70 \%$ at two different pond, the facultative pond (Pond 2) and the algae 2 (Pond 7).

\subsection{Heavy Metal Analysis}

The Fe ion concentration after POME is treated without zeolite is illustrated in Figure 3. Pond 2 has the highest Fe concentration with $11.52 \mathrm{mg} / \mathrm{L}$. The lowest is at Pond 7 , where the concentration is $0.74 \mathrm{mg} / \mathrm{L}$. Pond 4 and 5 contain Fe concentration of $2.92 \mathrm{mg} / \mathrm{L}$ and $0.95 \mathrm{mg} / \mathrm{L}$, respectively. However, when zeolite is used with POME treatment, the Fe ion concentrations notably dropped to 2.79 mg/L (Pond 2), 0.51 (Pond 4), 0.80 (Pond 5) and 0.03 (Pond 7). Pond 2 has reduction of Fe up to $75 \%$ from its initial concentration. Figure $\mathbf{3}$ (bar graph) also depicts the sorption efficiency. Pond 7 showed efficiency of 96\%, followed by Pond 4 (82.5\%), Pond 2 (75.8\%) and Pond 5 (16\%).

The $\mathrm{Zn}$ concentration is shown in Figure 4. When POME is treated without zeolite, $\mathrm{Zn}$ content is less than $1 \mathrm{mg} / \mathrm{L}$. The Pond 2, Pond 4, Pond 5 and Pond 7Zn concentrations are $0.75 \mathrm{mg} / \mathrm{L}, 0.55 \mathrm{mg} / \mathrm{L}, 0.17 \mathrm{mg} / \mathrm{L}$ and $0.12 \mathrm{mg} / \mathrm{L}$, respectively. However when POME is treated with zeolite, the $\mathrm{Zn}$ concentration reduced to $0.25 \mathrm{mg} / \mathrm{L}$ (Pond 2), 0.23 (Pond 4), 0.13 (Pond 5) and 0.10 (Pond 7). Figure 4 (bar graph) depicts the sorption efficiency.

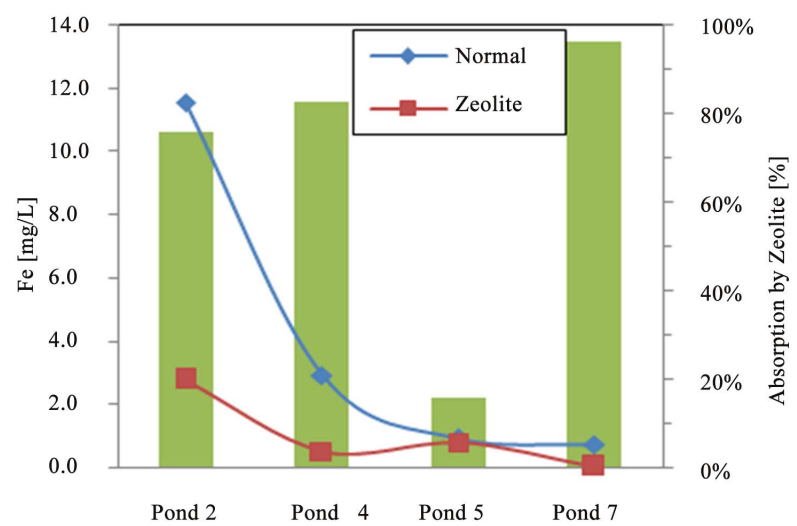

Figure 3. Fe content in ponds treated without and with zeolite as adsorbent. 


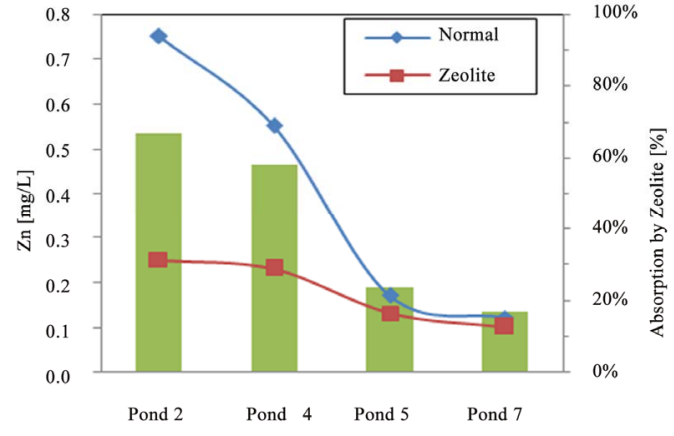

Figure 4. Zn content in ponds treated without and with zeolite as adsorbent.

Pond 2 showed efficiency of $66.7 \%$, followed by Pond 4 (58.2\%), Pond 5 (23.5\%) and Pond 7 (16.7\%).

Figure 5 illustrates the concentration of $\mathrm{Mn}$ when POME is treated without zeolite (normal) and with zeolite. The concentration of Mn is clearly different among all samples. Sample at Pond 2 have higher amount of Mn which is $1.78 \mathrm{mg} / \mathrm{L}$. The other ponds are having less than $0.35 \mathrm{mg} / \mathrm{L}$ concentration of $\mathrm{Mn}$. Pond 4, Pond 5 and Pond 7 have Mn concentration of $0.32 \mathrm{mg} / \mathrm{L}, 0.34 \mathrm{mg} / \mathrm{L}$ and $0.26 \mathrm{mg} / \mathrm{L}$, respectively. However when POME is treated with zeolite, the $\mathrm{Mn}$ concentration reduced to 0.44 mg/L (Pond 2), 0.1 (Pond 4), 0.01 (Pond 5) and 0.10 (Pond 7). Figure 5 (bar graph) depicts the sorption efficiency. Pond 2 showed efficiency of $75.3 \%$, followed by Pond 4 (68.8\%), Pond 5 (97.1\%) and Pond 7 (61.5\%). The Mn concentration at Pond 5 can be identified as trace, since the concentration is only $0.01 \mathrm{mg} / \mathrm{L}$.

According to Shavandi [19], the sorption capacities of 64.6\%, 53.6\% and 52.4\% for Fe, Zn and Mn were shown for natural zeolite, respectively. The study is experimented on first aerobic pond. In this study, when tested at different type of ponds, the capacity of zeolite to adsorb Fe, Zn and Mn is demonstrated in Figures 3-5. The highest heavy metal sorption for Fe concentration is 96.5\% at Pond 7. The highest heavy metal sorption for $\mathrm{Zn}$ concentration is $66.87 \%$ at Pond 2. The highest heavy metal sorption for Mn concentration is $96.81 \%$ at Pond 5. The performance of Zeolite in heavy metal sorption efficiency is different at different characteristic of treatment ponds. The highest concentration removal of Fe, $\mathrm{Zn}$ and Mn heavy metal is found at dissimilar ponds.

Consequently the reduction of metallic ions concentration of Fe, $\mathrm{Zn}$ and $\mathrm{Mn}$ is considered good as all samples are fulfilling the standard discharge limit for $\mathrm{Fe}, \mathrm{Zn}$ and Mn. This is similar to the studies done by [20] who found the natural zeolite is a promising adsorbent media that has a potential application as a metal ion adsorbent and has gained interest among researchers, particularly due to its ion exchange, molecular sieve properties and also its relatively high surface area. The metallic ions sorbent behavior of natural zeolites has been also studied by several researches, and it has been recognized as a promising sorbent for heavy metals [21].

\subsection{Turbidity Analysis}

The turbidity of all pond samples when POME is treated without (normal) and with zeolite is illustrated in Figure 6. The highest turbidity value is found at Pond 2, 4352 NTU. This indicates excessive turbidity, or cloudiness which caused by suspended matter or impurities that interfere with the clarity of the POME. These impurities may include finely divided inorganic and organic matter, soluble colored organic compounds. In addition, high turbidity in wastewater is an indication that the raw sample contains high amount of dissolved and suspended particles and ions. Dissimilar to Pond 7, the turbidity at Pond 7 is low and acceptable as it is the final treatment pond before the effluent is discharged at the river. The turbidity at Pond 4 and Pond 5 is 100 NTU and 54.3 NTU, respectively.

After the adsorption process by zeolite, turbidity at Pond 4, 5 and 7 have reduced to less than 20 NTU of turbidity, which is 19.5 NTU, 16.7 NTU and 7.4 NTU respectively. Pond 2 turbidity is measured at 1116.5 NTU after the treatment by zeolite. The ability of zeolite

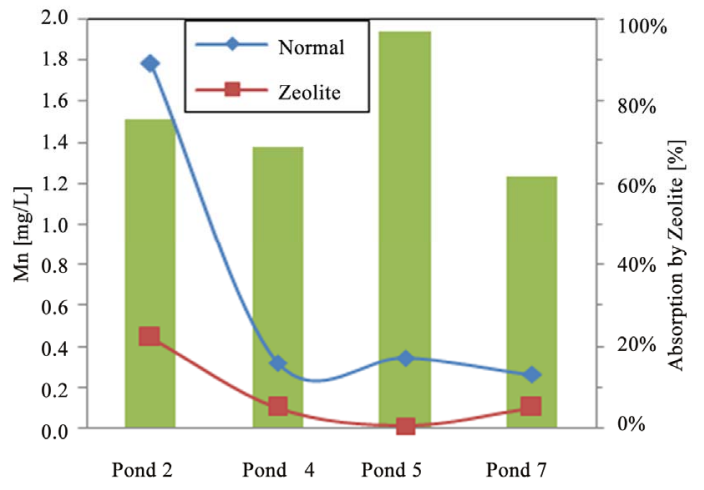

Figure 5. Mn content in ponds after treated without and with zeolite as adsorbent.

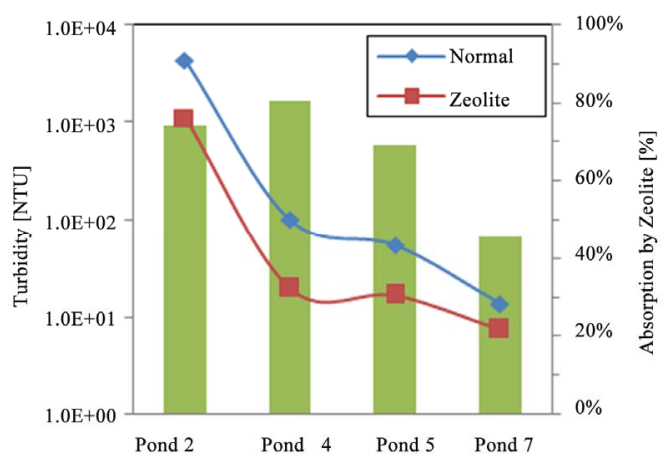

Figure 6. Turbidity content in ponds treated without and with zeolite as adsorbent. 
to remove turbidity is considered excellent as it can remove $80 \%$ of turbidity at Pond 4 , which is to the most efficient turbidity removal among all other pond. The performance of zeolite as a turbidity remover can be evident by its performance at Pond 2, Pond 5 and Pond 7 where the removal of turbidity is $74.3 \%, 69.2 \%$ and 45.6\% respectively. Figure 6 clearly demonstrate the ability of zeolite to remove reduce turbidity at different pond of POME treatment.

\section{Discussion}

Comparative studies are carried out to compare results from other investigators. Adsorption as a wastewater treatment process has aroused considerable interest during recent years. Commercial activated carbon is regarded as the most effective material for controlling the organic load. However, due to its high cost and about $10 \%-15 \%$ loss during regeneration, unconventional adsorbents like fly ash, peat, lignite, bagasse pith, wood, saw dust, periwinkle shells, etc. have attracted the attention of several investigations and adsorption characteristics have been widely investigated for the removal of refractory materials for varying degree of success [22]. Tables 4 and 5 summarize the adsorption process done at different types of wastewater and the percentage removal of selected parameters.

Table 4 clearly indicates that the most efficient adsorbent in reducing COD concentration is the avocado seed carbon (98.0\%). Zeolite is the least efficient of COD concentration removal capacity, 54.5\%. The adsorbents can be categorized into 4 level; percentage removal up to $80 \%$, percentage removal up to $70 \%$, and percentage removal up to $60 \%$. Zeolite is the only adsorbent with sorption capacity of COD concentration below than $60 \%$. Overall, the COD concentration adsorption efficiency of different adsorbents was in this order, avocado seed carbon $>$ animal horn $>$ fly ash $>$ activated charcoal $>$ brick kiln $>$ bagasse $>$ wood ash $>$ zeolite.

The efficiency of the adsorbents reducing the BOD concentration apparently shows the best adsorbent to treat BOD is the avocado seed carbon (99.2\%). This is followed by activated charcoal at sugar mill wastewater (80.4\%), bagasse (79\%), Zeolite (78\%), activated carbon at textile wastewater (74\%) and lastly the wood ash (60\%). All adsorbents have up to $60 \%$ capacity of reducing BOD concentration in different type of wastewater.

Four adsorbents have been studied and presented in Table 4, which can reduce the turbidity of wastewater. There are activated charcoal, bagasse, zeolite and wood ash. The highest turbidity reduction is by activated charcoal with the efficiency of $82.50 \%$. However, the ability of bagasse and zeolite is considered comparable since the removal efficiency is $80.6 \%$ and $80.5 \%$, respectively. The wood ash can only remove turbidity at $54.0 \%$ efficiency. There are inadequate research on turbidity removal as much of the study is concerning on color removal than the turbidity.

Numerous researches have been conducted on metallic ions sorption ability of natural zeolite on both aqueous solution and real wastewater as illustrated in Table 5.

Table 4. Comparison of different adsorbent ability.

\begin{tabular}{|c|c|c|c|c|}
\hline Adsorbent & Type of wastewater & Parameter & Removal Percentage & References \\
\hline Brick Kiln & Domestic Wastewater & COD & 83.2 & \multirow{2}{*}{ [25] } \\
\hline Fly ash & Domestic Wastewater & COD & 87.8 & \\
\hline Animal Horn & Industrial Wastewater & COD & 95.7 & [26] \\
\hline Avocado Seed Carbon & Coffee Processing Wastewater & COD BOD & 98.299 .2 & [27] \\
\hline \multirow{5}{*}{ Activated Charcoal } & \multirow[t]{2}{*}{ Textile Wastewater } & COD & 80.2 & \multirow[b]{2}{*}{ [28] } \\
\hline & & BOD & 74.0 & \\
\hline & \multirow[t]{3}{*}{ Sugar Mill Wastewater } & COD & 85.4 & \multirow{3}{*}{ [29] } \\
\hline & & BOD & 80.4 & \\
\hline & & Turbidity & 82.5 & \\
\hline \multirow{3}{*}{ Wood Ash } & \multirow[t]{3}{*}{ Sugar Mill Wastewater } & COD & 67.4 & \multirow{3}{*}{ [29] } \\
\hline & & BOD & 60.0 & \\
\hline & & Turbidity & 54.0 & \\
\hline \multirow{3}{*}{ Bagasse } & Sugar Mill Wastewater & COD & 79.0 & \multirow{3}{*}{ [29] } \\
\hline & & BOD & 79.0 & \\
\hline & & Turbidity & 80.6 & \\
\hline \multirow{3}{*}{ Zeolite } & POME Wastewater & COD & 54.5 & \multirow{3}{*}{ Current study } \\
\hline & & BOD & 78.0 & \\
\hline & & Turbidity & 80.5 & \\
\hline
\end{tabular}


Table 5. Comparison of natural zeolites ability for metallic ions removal.

\begin{tabular}{|c|c|c|c|c|}
\hline Adsorbent & Type of wastewater & Metal & $\%$ Removal & Reference \\
\hline \multirow[t]{2}{*}{ Brazilian Natural Scolecite } & Wastewater & $\mathrm{Mn}$ & 75.0 & {$[30]$} \\
\hline & Aqueous solutions & $\mathrm{Zn}$ & 53.8 & [31] \\
\hline \multicolumn{2}{|l|}{ Italian Sedimentary } & $\mathrm{Cu}$ & 66.3 & \\
\hline \multirow[t]{2}{*}{ Clinoptiloite } & & Cd & 37.3 & \\
\hline & & $\mathrm{Pb}$ & 74.5 & \\
\hline Turkey Natural Clinoptilolities & Aqueous solutions & $\mathrm{Zn}$ & 24.0 & {$[32]$} \\
\hline \multirow[t]{4}{*}{ Jordan Natural Zeolite } & Aqueous model solutions & $\mathrm{Fe}$ & 69.1 & [33] \\
\hline & Motorway stormwater & $\mathrm{Zn}$ & 10.1 & \\
\hline & & $\mathrm{Pb}$ & 44.2 & \\
\hline & & $\mathrm{Cu}$ & 32.4 & \\
\hline \multirow[t]{7}{*}{ New Zealand Mordenite } & & $\mathrm{Cd}$ & 6.0 & [13] \\
\hline & Synthetic solution & $\mathrm{Zn}$ & 41.8 & \\
\hline & & $\mathrm{Pb}$ & 89.2 & \\
\hline & & $\mathrm{Cu}$ & 53.4 & \\
\hline & Aqueous solutions & $\mathrm{Zn}$ & 45.9 & \\
\hline & & Mn & 19.8 & [34] \\
\hline & & $\mathrm{Cu}$ & 6.1 & \\
\hline \multirow{4}{*}{ Turkey Natural Zeolite } & Acid Amine drainage & $\mathrm{Zn}$ & 67.8 & \\
\hline & & $\mathrm{Fe}$ & 59.9 & {$[21]$} \\
\hline & & $\mathrm{Mn}$ & 18.9 & \\
\hline & POME (raw) & $\mathrm{Zn}$ & 53.6 & \\
\hline \multirow[t]{8}{*}{ Slovakian Natural Zeolite } & & $\mathrm{Fe}$ & 64.6 & [19] \\
\hline & & $\mathrm{Mn}$ & 52.4 & \\
\hline & POME & $\mathrm{Zn}$ & 66.9 & This study \\
\hline & Pond 2 (Mixing) & $\mathrm{Fe}$ & 75.7 & \\
\hline & & $\mathrm{Mn}$ & 75.4 & \\
\hline & Pond 4 (Anaerobic 1) & $\mathrm{Zn}$ & 58.7 & \\
\hline & & $\mathrm{Fe}$ & 82.4 & \\
\hline & & $\mathrm{Mn}$ & 68.1 & \\
\hline \multirow[t]{6}{*}{ Slovakian Natural Zeolite } & Pond 5 (Facultative) & $\mathrm{Zn}$ & 21.1 & \\
\hline & & $\mathrm{Fe}$ & 15.9 & \\
\hline & & $\mathrm{Mn}$ & 96.8 & \\
\hline & Pond 7 (Algae 2) & $\mathrm{Zn}$ & 19.3 & \\
\hline & & $\mathrm{Fe}$ & 96.5 & \\
\hline & & $\mathrm{Mn}$ & 60.0 & \\
\hline
\end{tabular}


The Slovakian zeolite used in this study has higher Zn sorption percentage compared to the majority of tested zeolites. However, Fe removal percentages of all studied zeolites are almost in the same range that is less than $70 \%$. In case of $\mathrm{Mn}$, the zeolite used in this study shows the higher removal ability than zeolite from Turkey, while Brazilian zeolite removed Mn ions more effectively. In this study case, the sorption capacity of the Slovakian zeolite to reduce the concentration of $\mathrm{Fe}, \mathrm{Zn}$ and $\mathrm{Mn}$ is different at different pond. This is maybe due to the different contents of metallic ions in all samples.

Overall, the adsorption process is one of the effective methods for pollutant removal from the waste effluent especially heavy metal ions, color, odor and organic pollution [23,24]. The process of adsorption has an edge over the other methods due to its sludge free clean operation and low capital intensive nature. Even though, zeolite has less adsorption capacity toward reducing COD concentration, the other abilities should not be overlooked. The present study evidenced that zeolite is excellent for the reduction of BOD concentration and removal sorption of metal and turbidity during POME treatment.

\section{Conclusion}

The characterization of POME has been carried out. The POME at Pond 2 has the highest concentration of all tested ponds due to the fact that it is the first receiver of POME. Due to the recent desludging activity at Pond 4 and Pond 5, BOD concentration in Pond 7 was slightly high. The POME at Pond 2, Pond 4, Pond 5 and Pond 7 has been treated through adsorption process by zeolite. The adsorption process shows a substantial reduction in COD, BOD, heavy metals and turbidity. This indicates the performance of zeolite as adsorbent is promising. The highest concentration removal is at Pond 2, thus applying zeolite in Pond 2 could result in positive step in reducing the POME treatment ponds in mills.

\section{REFERENCES}

[1] S. Arifand and T. A. Tengku Mohd Ariff, "The Case Study on the Malaysian Palm Oil," United Nations Conference on Trade and Development/Economic and Social Commission for Asia and the Pacific Regional Workshop on Commodity Export Diversification and Poverty Reduction in South and South-East Asia, Bangkok, 3-5 April 2001.

[2] G. D. Najafpour, A. A. LZinatizadeh, A. R. Mohamed, M. Hasnain Isa, H. Nasrollahzadeh, "High-Rate Anaerobic Digestion of Palm Oil Mill Effluent in an Upflow Anaerobic Sludge-Fixed Film Bioreactor," Process Biochemistry, Vol. 41, No. 2, 2006, pp. 370-379. doi:10.1016/j.procbio.2005.06.031

[3] R. Borja, C. J. Banks and E. Sánchez, “Anaerobic Treat- ment of Palm Oil Mill Effluent in a Two-Stage Up-Flow Anaerobic Sludge Blanket (UASB) Reactor," Journal of Biotechnology, Vol. 45, No. 2, 1996, pp. 125-135. doi:10.1016/0168-1656(95)00154-9

[4] S. Yacob, M. A. Hassan, Y. Shirai, M. Wakisaka and S. Subash, "Baseline Study of Methane Emission from Open Digesting Tanks of Palm Oil Mill Effluent Treatment," Chemosphere, Vol. 59, No. 11, 2005, pp. 1575-1581. doi:10.1016/j.chemosphere.2004.11.040

[5] C. O. Onyia, A. M. Uyub, J. C. Akunna, N. A. Norulaini and A. K. M. Omar, "Increasing the Fertilizer Value of Palm Oil Mill Sludge: Bioaugmentation in Nitrification. Sludge Management Entering the Third Millenium,” Industrial, Combined, Water and Wastewater Residues, Vol. 44, 2001, pp. 157-162.

[6] K. K. Chin, S. W. Lee and H. H. Mohammad, “A Study of Palm Oil Mill Effluent Treatment Using a Pond System," Water Science and Technology, Vol. 34, No. 1, 1996, pp. 119-123. doi:10.1016/S0273-1223(96)00828-1

[7] A. W. Chester and E. G. Derouane, "Zeolite Characterization and Catalysis,” Springer, Heidelberg, London, New York, 2001.

[8] D. Mohan and K. P. Singh, "Single- and Multi-Component Adsorption of Cadmium and Zinc Using Activated Carbon Derived from Bagasse-An Agricultural Waste," Water Research, Vol. 36, No. 9, pp. 2304-2318. doi:10.1016/S0043-1354(01)00447-X

[9] V. J. Inglezakis, M. D. Loizidou and H. P. Grigoropoulou, "Ion Exchange of $\mathrm{Pb}^{2+}, \mathrm{Cu}^{2+}, \mathrm{Fe}^{3+}$, and $\mathrm{Cr}^{3+}$ on Natural Clinoptilolite: Selectivity Determination and Influence of Acidity on Metal Uptake,” Journal of Colloid and Interface Science, Vol. 261, No. 1, pp. 49-54. doi:10.1016/S0021-9797(02)00244-8

[10] S. Mohan and R. Gandhimathi, "Removal of Heavy Metal Ions from Municipal Solid Waste Leachate Using Coal Fly Ash as An Adsorbent," Journal of Hazardous Materials, Vol. 169, No. 1-3, 2009, pp. 351-359.

[11] Z. Milán, E. Sánchez, P. Weiland, R. Borja and A. Marti, "Influence of Different Natural Zeolite Concentrations on the Anaerobic Digestion of Piggery Waste,” Bioresource Technology, Vol. 80, No. 1, 2001, pp. 37-43. doi:10.1016/S0960-8524(01)00064-5

[12] T. S. Jamil, H. S. Ibrahim, I. H. Abd El-Maksoud, S. T. El-Wakeel, “Application of Zeolite Prepared from Egyptian Kaolin for Removal of Heavy Metals. I. Optimum Conditions,” Desalination, Vol. 258, No. 1-3, 2010, pp. 34-40. doi:10.1016/j.desal.2010.03.052

[13] S. K. Pitcher, R. C. T. Slade and N. I. Ward, "Heavy Metal Removal from Motorway Stormwater Using Zeolites," Science of The Total Environment, Vol. 334-335, 2004, pp. 161-166. doi:10.1016/j.scitotenv.2004.04.035

[14] T. Motsi, N. A. Rowson and M. J. H. Simmons, “Adsorption of Heavy Metals from Acid Mine Drainage by Natural Zeolite,” International Journal of Mineral Processing, Vol. 92, No. 1-2, 2009, pp. 42-48. doi:10.1016/j.minpro.2009.02.005

[15] A. N. Ma, “Treatment of Palm Oil Mill Effluent,” In: G. Singh, K. H. Lim, T. Leng and L. K. David, Ed., Oil Palm and the Environment: A Malaysian Perspective, 
Malaysian Oil Palm Growers' Council, Kuala Lampur, 1999, pp. 113-126.

[16] R. Khalid and W. A. Wan Mustafa, "External Benefits of Environmental Regulation: Resource Recovery and the Utilisation of Effluents," The Environmentalist, Vol. 12, No. 4, 1992, pp. 277-285. doi:10.1007/BF01267698

[17] S. Sethupathi, "Removal of Residue Oil from Palm Oil Mill (POME) Using Chitosan,” Universiti Sains Malaysia, Vol. 41, 2004, pp. 962-964.

[18] N. F. Gray, "Biological of Wastewater Treatment," Oxford University Press, Oxford, 1992.

[19] M. A. Shavandi, Z. Haddadian, M. H. S. Ismail, N. Abdullah and Z. Z. Abidin, "Removal of Fe(III), Mn(II) and Zn(II) from Palm Oil Mill Effluent (POME) by Natural Zeolite," Journal of the Taiwan Institute of Chemical Engineers, Vol. 43, 2012, pp. 750-759. doi:10.1016/j.jtice.2012.02.014

[20] S. Mohan and R. Gandhimathi, "Removal of Heavy Metal Ions from Municipal Solid Waste Leachate Using Coal Fly Ash as An Adsorbent," Journal of Hazardous Materials, Vol. 169, No. 1- 3, 2009, pp. 351-359.

[21] E. Erdem, N. Karapinar and R. Donat, "The Removal of Heavy Metal Cations by Natural Zeolites,” Journal of Colloid and Interface Science, Vol. 280, No. 2, 2004, pp. 309-314. doi:10.1016/j.jcis.2004.08.028

[22] K. K. Pandey, G. Prasad and V. N. Singh, "Copper Removal from Aqueous Solutions by Fly Ash,” Water Research, Vol. 19, No. 7, 1985, pp. 869-873. doi:10.1016/0043-1354(85)90145-9

[23] M. Ganji, M. Khosravi and R. Rakhshaei, "Biosorption of $\mathrm{Pb}, \mathrm{Cd}, \mathrm{Cu}$ and $\mathrm{Zn}$ from the Wastewater by Treated Azollafiliculides with $\mathrm{H} 2 \mathrm{O} 2 / \mathrm{MgCl} 2$," International Journal of Environmental Science and Technology, Vol. 1, No. 4, 2005, pp. 265-271.

[24] M. B .G. Steinhauser, "Adsorption of Ions onto High Silica Volcanic Glass,” Applied Radiation and Isotopes, Vol. 66, No. 1, 2008, pp. 1-8. doi:10.1016/j.apradiso.2007.07.010

[25] R. Devi and R. P. Dahiya, "Chemical Oxygen Demand (Cod) Reduction in Domestic Wastewater By Fly Ash And Brick Kiln Ash,” Water, Air \& Soil Pollution, Vol. 174, No. 1-4, 2006, pp. 33-46. doi:10.1007/s11270-005-9022-9

[26] E. O. Aluyor and O. A. M. Badmus, “COD Removal from Industrial Wastewater Using Activated Carbon Prepared from Animal Horns,” African Journal of Biotechnology,Vol. 7, No. 21, 2008, pp. 3887-3891.

[27] R. Devi, "Innovative Technology of COD and BOD Reduction from Coffee Processing Wastewater Using Avocado Seed Carbon (ASC),” Water, Air, \& Soil Pollution, Vol. 207, 2010, pp. 299-306. doi:10.1007/s11270-009-0137-2

[28] H. Patel and R. T. Vashi, "Treatment of Textile Wastewaterby Adsorption and Coagulation," E-Journal of Chemistry, Vol. 7, No. 4, 2010, pp. 1468-1476. doi:10.1155/2010/987620

[29] C. Saxena and S. Madan, "Evaluation of Adsorbents Efficacy for the Removalof Pollutants from Sugar Mill Effluent," ARPN Journal of Agricultural and Biological Science, Vol. 7, No. 5, 2012, pp. 325-329.

[30] S. M. Dal Bosco, R. S. Jimenez and W. A. Carvalho, "Removal of Toxic Metals from Wastewater by Brazilian Natural Scolecite,” Journal of Colloid and Interface Science, Vol. 281, No. 2, 2005, pp. 424-431. doi:10.1016/j.jcis.2004.08.060

[31] A. Langella, M. Pansini, P. Cappelletti, B. D. Gennaro, M. de' Gennaro and C. Colella, " $\mathrm{NH}^{4+}, \mathrm{Cu}^{2+}, \mathrm{Zn}^{2+}, \mathrm{Cd}^{2+}$ and $\mathrm{Pb}^{2+}$ Exchange for $\mathrm{Na}^{+}$in a Sedimentary Clinopti-Lolite, North Sardinia, Italy," Microporous and Mesoporous Materials, Vol. 37, No. 3, 2000, pp. 337-343. doi:10.1016/S1387-1811(99)00276-0

[32] C. Semra, "The Removal of Zinc Ions by Natural and Conditioned Clinoptilolites,” Desalination, Vol. 225, No. 1-3, 2008, pp. 41-57.

[33] M. Al-Anber and Z. A. Al-Anber, "Utilization of Natural Zeolite as Ion-Exchange and Sorbent Material in the Removal of Iron,” Desalination, Vol. 225, No. 1-3, 2008, pp. 70-81. doi:10.1016/j.desal.2007.07.006

[34] A. Sdiri, T. Higashi, T. Hatta, F. Jamoussi and N. Tase, "Evaluating the Adsorptive Capacity of Montmorillonitic and Calcareous Clays on the Removal of Several Heavy Metals in Aqueous Systems," Chemical Engineering Journal, Vol. 172, No. 1, 2011, pp. 37-46. doi:10.1016/j.cej.2011.05.015 